\title{
A new Drosophila homeo box gene is expressed in mesodermal precursor cells of distinct muscles during embryogenesis
}

\author{
Cord Dohrmann, ${ }^{1}$ Natalia Azpiazu, and Manfred Frasch \\ Max-Planck-Institut für Entwicklungsbiologie, Abteilung III Genetik, D-7400 Tübingen, Germany
}

Several Drosophila homeo box genes have been shown to control cell fates in specific positions or cell groups of the embryo. Because the mechanisms involved in the pattern formation of complex internal organs, such as the musculature and the nervous system, are still largely unknown, we sought to identify and analyze new homeo box genes specifically expressed in these tissues. Here, the molecular analysis and expression pattern of one such gene, containing both a homeo box and a PRD repeat, is described. This gene, designated S59, is expressed in a small number of segmentally repeated mesodermal cells $\sim 2 \mathrm{hr}$ postgastrulation. Gradually, four groups of S59-expressing mesodermal cells appear in each abdominal hemisegment, each one giving rise to a particular somatic muscle after fusion with surrounding myoblasts. Thus, individual precursors for particular muscles, which we call "founder cells," are specified relatively early during mesodermal development. The expression of a particular homeo box gene in these cells suggests that distinct programs of gene expression are active in subsets of mesodermal cells after germ band elongation, resulting in a specification of their developmental fates. In addition to the mesoderm, S59 is expressed in a subset of neuronal cells of the CNS and their precursors and also in cells of a small region of the midgut.

[Key Words: Drosophila; homeo box; muscle development; mesodermal and neuronal genes; midgut]

Received July 9, 1990; revised version accepted August 27, 1990.

Many genes involved in embryonic pattern formation of Drosophila have been isolated in genetic screens for mutants displaying cuticular defects (Jürgens et al. 1984; Nüsslein-Volhard et al. 1984; Wieschaus et al. 1984). Mutations in one group of genes acting early during embryonic development lead to strong disruptions of the cuticle pattern. The maternally expressed coordinate genes, the gap genes, the pair-rule genes (Nüsslein-Volhard and Wieschaus 1980), and the neurogenic genes (Lehmann et al. 1983) belong to this group. Mutations in other genes affect the cuticle pattern because their wildtype products specify positional information in the epidermis itself that secretes the cuticle. Examples of such genes are the segment polarity genes and the homeotic genes (Lewis 1978; Ingham 1988). The molecular analysis of pattern formation genes has suggested that a large number of them act as transcriptional regulators. Many of these genes contain a motif called the homeo box, which is highly conserved among different members of this family and encodes a protein sequence of $\sim 60$ amino acids, the homeo domain (McGinnis et al. 1984; Scott et al. 1989). This protein domain has structural similarity to the DNA-binding domains of bacterial repressor proteins (Qian et al. 1989). Both in vitro and in vivo experiments have shown that the homeo domain is

1Present address: Department of Anatomy and Cellular Biology, Harvard Medical School, Boston, Massachusetts 02115 USA. essential for the DNA-binding activity and the biological activity of homeo box gene products (Desplan et al. 1985; Hoey and Levine 1988; Kuziora and McGinnis 1989|. It is thought that the products of homeo box genes specify single cells, tissues, or segmental regions of the embryo by the transcriptional regulation of target genes. Thus, different programs of gene expression are realized in cells expressing different homeo box genes, resulting in a characteristic differentiation program for each of these cells.

The genetic screens for mutants with a disrupted cuticle pattern largely restricted the identification of genes involved in specifying cell fates to those acting upon the epidermis. Some of these genes were subsequently found to have additional functions in internal organs. For example, the homeo box genes involved in segmentation, fushi tarazu (ftz) and even-skipped (eve), also specify neuronal identities in the central nervous system (CNS) (Doe et al. 1988a,b). The homeo box gene cut, originally discovered through the cuticle phenotype of mutant adult flies, also specifies sensory organ identities in the embryo (Blochlinger et al. 1988), and the homeotic gene Ultrabithorax $(U b x)$ has additional roles in neuronal and muscle development (Hooper 1986; Doe and Scott 1988). It is likely that most of the genes specifying cell fates in internal organs such as the muscles and the nervous system do not strongly affect the cuticle and, therefore, have escaped the mutational screens for embryonic pat- 
tern formation genes. An alternative approach is, first, to identify such genes by their molecular structures and, then, to generate mutations for them. Because it is likely that several other genes involved in the specification of internal organs are members of the homeo box gene family, screens to isolate novel homeo box genes utilizing the pronounced sequence homology among divergent homeo boxes have been performed (Levine et al. 1985; Barad et al. 1988; Dalton et al. 1989; Kim and Nirenberg 1989). As described here, one of the newly isolated homeo box genes, called S59, is expressed exclusively in nonepidermal cells in embryos of postgastrulation stages. In particular, S59 expression is restricted to specific muscles of the somatic mesoderm, to subsets of neurons of the CNS, and to a small region of the midgut. Using an antibody directed against the 559 protein, we have identified "founder" cells for particular muscles. These cells are present in very early stages of development of the somatic mesoderm. We present a description of the fates of these cells through the stages when they fuse into syncytia, which then differentiate into the larval muscle fibers.

So far, no mutations are available for the 559 gene that would reveal its functions during embryonic development. However, the detailed analysis of the S59 expression pattern has provided clues to its potential functions. Our observations suggest that S59 may play a role in specifying the identity of particular somatic muscles and neurons of the CNS.

\section{Results}

Isolation and molecular organization of the S59 homeo box gene

The genomic clone 559 was isolated in a screen of a Drosophila DNA library for sequences cross-hybridizing with the homeo box region of the homeotic gene Sex combs reduced (Scr; Levine et al. 1985). S59 maps to 93E3.4 on chromosome 3R. We have isolated genomic regions flanking S59 by genomic "walking." S59 was found to map $\sim 48 \mathrm{~kb}$ to the right of the distal breakpoint of $D f(3 R) e^{F 1}$, estimated to be at 93E1.2 (Scalenghe and Ritossa 1977; data not shown). Restriction maps of S59 and the overlapping clones S5-1 and S3-1 are shown in Figure 1.

A 2.8-kb EcoRI fragment of S59 cross-hybridizing with the $S c r$ homeo box was used to isolate cDNAs from embryonic cDNA libraries. From screens of a total of $1,300,000$ cDNA clones, 10 S59 cDNAs were obtained with lengths between 1.0 and $2.6 \mathrm{~kb}$. Restriction analysis showed that the internal structures of all cDNAs were identical with variations found only at their $3^{\prime}$ and $5^{\prime}$ ends. Three cDNA clones, including S59/2, had inserts of $2.6 \mathrm{~kb}$. The other cDNAs, including S59/4 (2.4 $\mathrm{kb} /$ were shorter at their $5^{\prime}$ ends, but had an extension at their $3^{\prime}$ ends of $\sim 60 \mathrm{bp}$.

The S59/2 cDNA hybridized with genomic sequences covering a region of $8.5 \mathrm{~kb}$ (Fig. 1), and the 559 transcription unit was found to contain three introns. The bound- aries between introns and exons were accurately determined by sequencing of the relevant genomic fragments (see Fig. 2).

Using single-stranded dideoxynucleotide sequencing, we have determined the entire nucleotide sequence of the S59/2 and S59/4 cDNAs (Fig. 2A). The S59/2 cDNA contains $2616 \mathrm{bp}$, and the 5' end of the S59/4 cDNA corresponds to nucleotide 259 of S59/2. The S59/4 cDNA extends 56 bp farther to the $3^{\prime}$ end and, unlike S59/2, contains the polyadenylation signal AATAAA 19-bp upstream from its poly(A) tail. The 2672 nucleotides of the combined S59/2 and S59/4 cDNAs without poly(A) closely match the S59 mRNA size of $2.8 \mathrm{~kb}$ as determined by Northern analysis (see below). The sequence AGCATTT at position -12 to -6 strongly resembles the consensus sequence for transcription start sites AT. $\mathrm{CA}^{\mathrm{G}}{ }_{\mathrm{T}} \mathrm{T}_{\mathrm{T}}$ (Hultmark et al. 1986).

A long open reading frame (ORF) extends from nucleotide 296 to 2302 of the S59 cDNA. The nucleotide sequence AAAA, preceding the first ATG (at nucleotide 326) of this ORF, perfectly matches the consensus sequence for Drosophila translation start sites (Cavener 1987). This ORF is predicted to encode a polypeptide of 659 amino acids with a molecular mass of $70 \mathrm{kD}$. The homeo domain is located close to the carboxyl terminus, between amino acids 545 and 605 . The sequence of this homeo domain has also been reported by Kim and Nirenberg (1989; NK-1).

A comparison with other published homeo domains shows that the sequence of this homeo domain has been highly conserved during evolution (Fig. 2C). Close homologs with only several amino acid exchanges have been identified in the honey bee ( $\mathrm{H} 40$; Walldorf et al. 1989) and in chicken (CHox3; Rangini et al. 1989). The homeo domain of the Caenorhabditis elegans gene JML1001 (listed in Scott et al. 1989) also displays a high sequence similarity $(82 \%)$ to the 559 homeo domain. In Drosophila, the S59 homeo domain is most closely related to that of msh (muscle segment homeo box; Robert et al. 1989) and zerknüllt (zen; Rushlow et al. 1987), sharing an amino acid identity of $57 \%$ with each of them (Kim and Nirenberg 1989).

The amino-terminal part of S59 contains a PRD-(HisPro) repeat beginning at amino acid 176. The S59 PRD repeat displays the highest similarity to the PRD-repeat and adjacent sequences of paired (prd; Frigerio et al. 1986), and a somewhat lower similarity to the bicoid PRD repeat (Berleth et al. 1988). A comparison between these PRD repeats is shown in Figure 2D. A genomic clone (no. 9) isolated by Frigerio et al. (1986) with the HisPro repeat of prd also contains S59 (M. Frasch, unpubl.). Other conspicuous amino acid sequences include a polyalanine stretch (amino acids 364-372), and an acidic domain followed by a polyglycine stretch just amino-terminal to the homeo domain (Fig. 2B). Regions of similar amino acid compositions were also identified in other Drosophila homeo box genes (Poole et al. 1985; Baumgartner et al. 1987; Frasch et al. 1987; Blochlinger et al. 1988) and in yeast transcription factors (Hope and Struhl 1986; Ma and Ptashne 


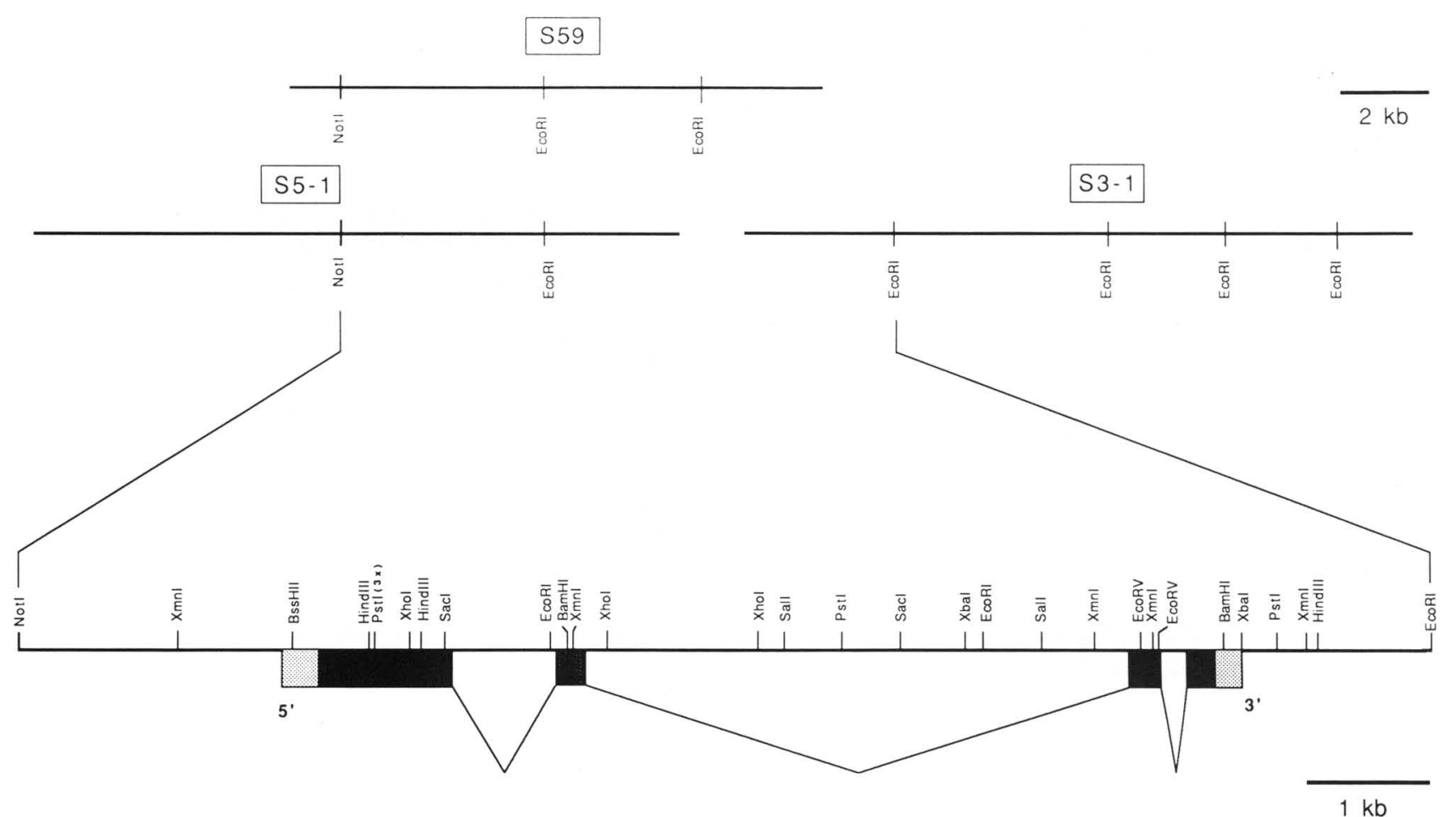

Figure 1. Organization of the S59 transcription unit. (Top) The restriction maps and the alignment of three genomic phage clones from the S59 region; (below) a finer restriction map of the genomic region corresponding to the S59 transcription unit in a larger scale. The boxes indicate exons, as determined by hybridizations with cDNAs and by sequencing. The lightly shaded regions represent untranslated leader and trailer sequences of the S59 transcript.

1987). There is no indication yet of the functional significance of such protein sequences in Drosophila.

\section{S59 mRNA expression}

In Northern analysis of poly $(A)^{+}$RNA from different developmental stages, a single transcript with a size of 2.8 $\mathrm{kb}$ is detected using the S59/2 cDNA as a probe (Fig. 3). A strong signal first appears at 8-12 hr of embryonic development and increases slightly in the 12- to 24-hr period. During the larval and pupal stages, and in adult males, the expression is strongly reduced. A much higher level of 559 mRNA is observed in adult females.

\section{S59 protein expression}

In situ hybridizations with sectioned and whole-mount embryos indicated that the S59 mRNA is expressed mainly in cells of the somatic mesoderm and the CNS. To study the spatial expression pattern of S59 in detail, we produced polyclonal antibodies against an 559 polypeptide. These antibodies specifically recognize the S59 protein; embryos lacking the S59 gene [derived from $\mathrm{Df}\left(3 \mathrm{R} / \mathrm{e}^{\mathrm{D} 7}\right.$; Scalenghe and Ritossa 1977) do not stain (not shown). The S59 protein is expressed in small subsets of cells in the somatic mesoderm, in muscles, in the CNS, and in a small region of the midgut. As expected for a homeo domain protein, the S59 protein is strictly localized to the nuclei of these cells.
Muscle expression Following invagination during gastrulation, the mesodermal cells spread to form a layer under the epidermis and undergo three mitotic divisions (Campos-Ortega and Hartenstein 1985). After the third division the mesoderm separates into two layers: the somatic mesoderm (somatopleura), contacting the epidermis; and the visceral mesoderm (splanchnopleura), contacting the yolk sac in a dorsolateral position.

S59 protein is first expressed at mid stage 11 of embryogenesis $\mid 6-7 \mathrm{hr}$ of development; Campos-Ortega and Hartenstein 1985), during the period of the third mesodermal mitosis. Initially, S59 occurs in a single mesodermal cell located ventrally in each hemisegment (Fig. 4A and B; this cell and its progeny are called I). Double staining with antibodies against $\mathrm{S} 59$ and twist, which is expressed in all mesodermal cells at this stage (Thisse et al. 1988), shows that the S59-expressing cells are considerably larger than the average mesodermal cells (Fig. 5A). Cross sections of embryos stained with both S59 and twist antibodies clearly show that the S59expressing cells belong to the somatopleura (Fig. 5B). After the third mitotic division, in late stage 11, both daughter cells of I express S59. At the same time, a second cluster of mesodermal cells (II) starts to express S59 (Fig. 4C and D), and differences can be observed between abdominal and more anterior segments for the first time. Whereas cluster II contains four cells in each abdominal segment, more cells express S59 in the thoracic segments and the labial segment. Double staining 
11 CCACAGGCACACAACACGGCACATCTGTTGGATTAAGAaCTCGGAGAAATCGGAAACAACCCTCATCAT:ACGCZTCTGGCTCTTGAGCGTGTGAGTCGTCGCGC 116 GCGGATTACGACCAGGATAATCGGACGTCGGACCACGACCSCAGCAGCGGCAGCATAGGCAGCGTCCACGTCGGATATTGGCATCTCCGGATTCAGTCGATTGGC

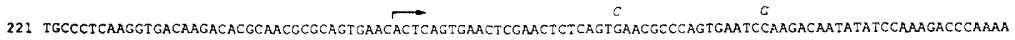
326 ATGGTCATGTTGCAATCGCCGGGGCAAAAGGCCAGCGATAGTGCGTCAGCCCAAAACACAGCCGTCGGTGGCCTGATGAGTCCCAACTCGAACCCGGACTCGCCC

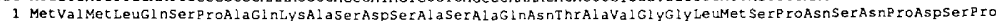

431 AAGTCCAACACCTCGCCGGATGTGGCGAGTGCGGACAGTGTGGTGTCCGGCACAGGCGCTGGCAGCACTCCGCCAGCGGCCAAGATACCCAAGTTCATCATCAGC

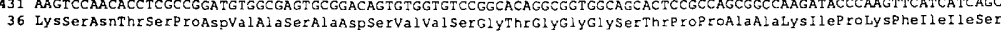

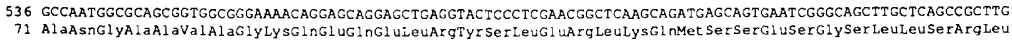
641 AGCCCCTTGCAGGAGGACTCCCAGGATAAGGAGAAGCCCAATCACAACAACAATAACAGTCTAACTAATCACAATGCAAACAGCAATACACGTCGCTCGCAATCC

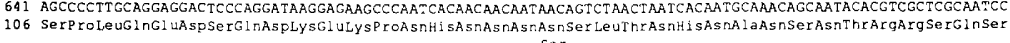
206 Serprol

746 CCTCCAGCATCGGTGGGATCCGTAAGCTTCTCCTCGCCAGCCCAGCAGCGAAAGCTCCTGGAACTCAATGCTGTGCGCCACTTGGCAAGGCCGGAGCCACTGCAG

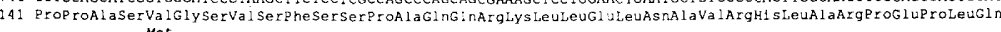
851 CATCCTCATGCGGCCCTGCTGCAGCAGCATCCCCACTTGCTGCAGAATCCGCAGTTCCTGGCCGCCGCCCAGCAGCACATGCACCATCATCAGCATCAACATCAC

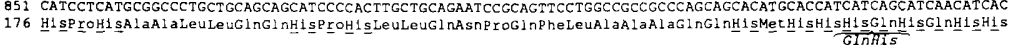
956 CAGCATCCCGCACATCCGCATTCGCATCAGCATCCGCATCCACACCCTCATCEGCATCCCCATCCGCATCCGTCGGCGGTCTTTCATT TGAGGGCTCCCAGCAGC

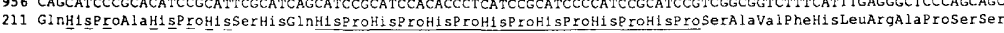

1061 AGCAGCACTGCCCCACCCTCGCCGGCCACC TCGCCCCTGTCGCCGCCCACATCCCCGGCCATCCATTCGGACCAGCAGATGAGTCCACCCATCGCTCCCCCCCAA 1166 AATCCGCCACATTCCTCGCAGCCACCACAACAGCAGCAGGTTGCCGCACCATCGGACATGGATCTCGAGCGGATTAAGCTGGTGGCTGCGGTGGCAGCCCGCACO

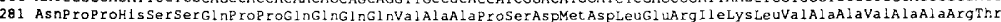
1271 ACTCAAGCTTCCAGCACCTCCGCCTTGGCGTCCGCCTCGAACTCCGTGTCCAATGCCAG C $C$ TCTCCATCTCCAACTCCAGCTCCGGATCGCCCAGTGGACGCGAC

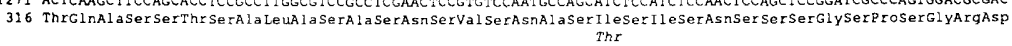

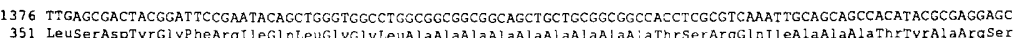
】

481 GACACCAGCGAGGAGCTCAACGTCGATGGCAACGACGAGGACAGCAACGATGGATCGCACAGCACGCCG CGGTCTGCCCAGTGGATCTGACGCGATCGGTGAAC

1586 AGCAGTGCTGCGGCGAATCCGAGTTCGGCCTCCACGAGTGCCTCCAGTGATCGAGATGCGGCCACAAAGCGGCTGGCCTTCTCCGTAGAGAACATACTGGATCCG

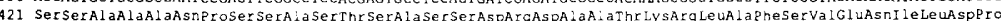

1691 AACAAGTTCACGGGCAACAAGCTGCCAAG:GGTCCTTTCGGCCATCCCAGGCAGTGGAGCTACGAGAGGGACGAGGAAATGCAGGAGCGATTGGATGACGAICAG

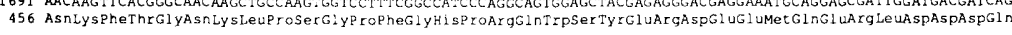
1

1796 AGCGAGGATATGTCTGCCCAGGATT T GAATGACATGGATCAGGACGATATGTGTGACGATGGCAGCGATATCGACGATCCCAGCAGCGAGACGGACTCCAAAAAG 1901 GGAGGCAGTCGTAATGGGGATGGAAAGTCCGGAGG:GGCGGCGGAGGTGGTTCAAADCTCGACGAGCCCGCACCGCCTTCACGTACGAACAACTAGTTTCCCTG

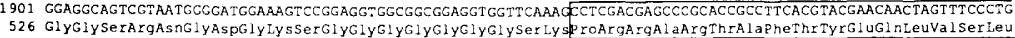
$2006 \frac{1}{\text { GAGAACAAGTTCAAGACCACCAGATATCTCACCGTCTGCGAGCGACTGAACTTGGCCCTCACCTTGAGCCTGACAGAGACGCAGGTTAAAATTTGGTTCCAGAAC }}$

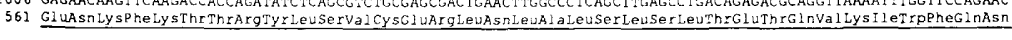

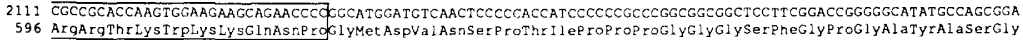
2216 CTCCTGTACTCGCACGCGGTGCCCTATCCCCCATACGGCCCCTACTTCCACCCCCTGGGCGCACATCACCTCAGCCACTCGCACTCATAAAATTGCAAGATGCAA

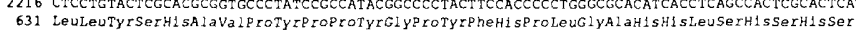

2321 CAGCGATTGTTGCAACTGTTCGAAAAGCGCGGCCGGGCGGTGGGGGGAGGGGCAGGTCCTGCGGCCGGAAGTGGATCGGTGGATCCCAAGGATAAAATGTAAATG 2426 TCAAACTGCTTTAAGTGTGTGT TTAGTGTTCGACCAGAGATTTCCTTIGTTACTTCGATTCTTTCGATTACCCGCTGTATATAGTTTT TGTAAAATATACTTACT 2531 ATGCTAGTGCTTAGAACCTCGAATGCCATATCTAGATTTAAATTATACAATTACCTGTAGCGTTTAAGTGGCAAGCAAAATCAAAAAAARAAA
2636 ATAAATGTCAAGTGAAAAAATAAACATTTTGAAAACTAAAAAAARAA
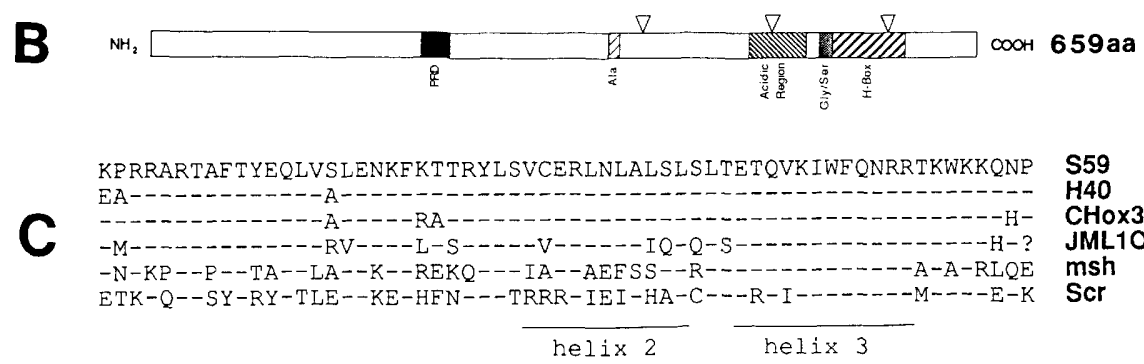

Figure 2. (See following page for legend.) 


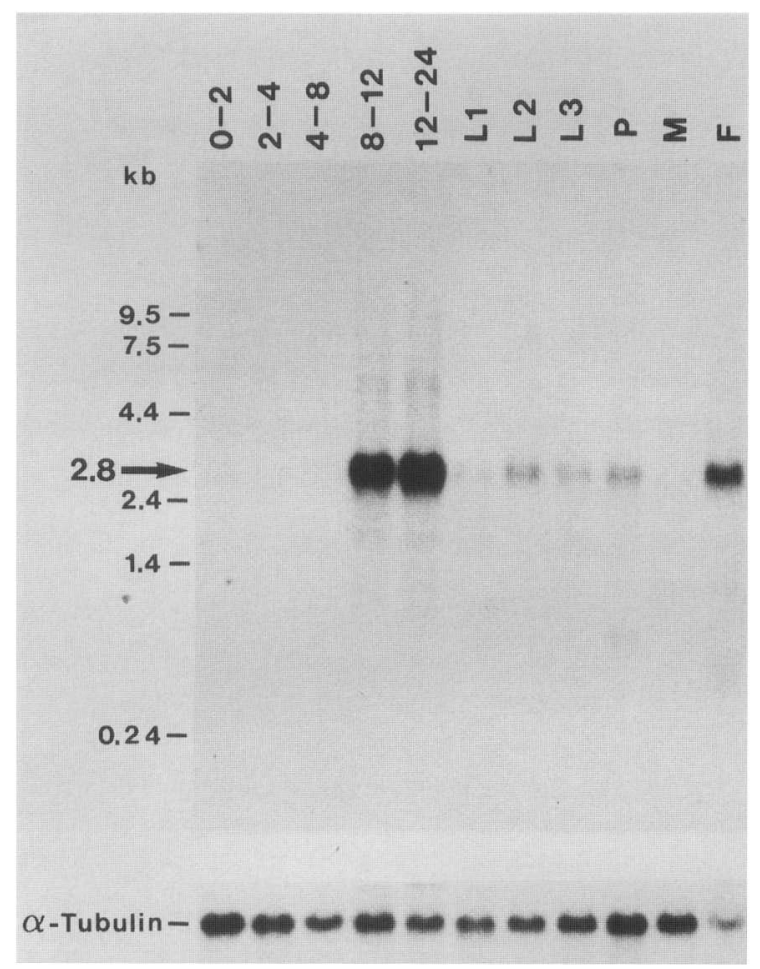

Figure 3. Northern analysis of S59 mRNA expression through the Drosophila life cycle. Poly $(\mathrm{A})^{+}$RNA from 0- to 2-hr, 2- to 4-hr, 4- to 8-hr, 8- to 12-hr, and 12- to 24-hr embryos, from first (L1)-, second (L2)-, and third (L3)-instar larvae, from pupae (P), and from adult males $(M)$ and females $(F)$ was tested. The same blot was hybridized with an $\alpha$-tubulin probe to estimate the relative amounts of poly $|A|+$ RNA loaded in each lane. The S59 mRNA size of $2.8 \mathrm{~kb}$ was determined using an RNA ladder (BRL) as a standard.

with 559 and twist antibodies (Fig. 5C) shows that the cells of cluster II are located at the tips of the parasegmental bulges of the mesoderm. This corresponds to a position at the parasegmental borders, as shown by double staining with an en antibody (Fig. 5D), whereas the cells of type I cells are located close to the anterior segment borders. In stage 12, during the retraction of the germ band, an additional pair of mesodermal cells (III), located in a lateral position at the parasegmental border, starts to express S59 (Fig. 4E and F; Fig. 5D). Cells of the III type are only seen in abdominal segments. The segmental positions of the stained cells with respect to the overlying ectoderm are maintained throughout development, with the exception of the cells Ia, which move anteriorly into the adjacent abdominal segments (Fig.
$4 \mathrm{E}-\mathrm{H})$. When comparing the $\mathrm{S} 59$ and en patterns, we do not observe a shift of the mesoderm against the epidermis at germ-band retraction, as proposed previously (Akam and Martinez-Arias 1985).

In stage 13, after retraction of the germ band, myoblasts fuse with each other to form syncytia. In embryos stained with S59 antibodies, we observe that S59-expressing cells both fuse with each other and also with neighboring cells. In Figure 4, G and H, an example is shown where the dorsal-most cell of the III pair has just fused with cells located more dorsally (arrowheads). Directly after fusion, the S59 signal is somewhat weaker in all nuclei of the syncytia, which we attribute to the dilution of S59 protein and/or mRNA. However, soon after fusion, full levels of 559 protein are restored in all nuclei within a syncytium (Fig. 4I,J), with the exception of the syncytia derived from cell Ia (Fig. 4J) where expression of S59 protein ceases soon after fusion (Fig. 4I). Thus, in late embryonic stages, S59 is expressed in three muscle fibers of each abdominal hemisegment: two located in the ventral group, and one in the pleural group (Fig. 4I, $\mathrm{K}_{\text {; }}$ Fig. 5H,I). Using the nomenclature of Crossley (1965, 1978), we identified these muscles as 25 (derived from the $\mathrm{S} 59$ cell Ib), 27 (derived from II), and 18 (derived from III). The muscle transiently expressing S59 corresponds to 5. The development of muscles expressing S59 in an abdominal segment is summarized schematically in Figure 6.

In the first abdominal segment and in the thorax, the cells Ia and Ib do not undergo migration as in more posterior segments and do not fuse with additional myoblasts. Consequently, the muscle 25 derived from cell Ib is absent in Al (and in thoracic segments), as reported previously (Campos-Ortega and Hartenstein 1985). In general, the pattern of S59-expressing muscles in the thoracic and gnathal segments is different from that of the abdominal segments. In these segments the number of nuclei containing S59 remains constant after stage 11, and S59 cells probably fuse only with each other or in some cases form fibers with single nuclei (Fig. $4 \mathrm{~K}$ ). In the telson, four muscles express S59 (Fig. 4L).

Previously, it has been difficult to follow the fate of individual myoblasts and muscles during development. The 559 antibody now provides a marker to analyze the morphogenesis of particular muscles, as illustrated in Figure $5 \mathrm{E}-\mathrm{H}$ for the abdominal muscles expressing S59. These embryos were double stained for S59 and muscle myosin. In Figure 5E (stage 13), fusion of S59-positive myoblasts Ib and II with neighboring myoblasts has just occurred, and the outlines of the syncytia as well as some unfused myoblasts can be seen. In the abdomen,

Figure 2. Sequences of S59 cDNAs. $(A)$ Nucleotide sequences and predicted amino acid sequences of the cDNAs S59/2 and S59/4. The sequences derived from S59/2 are shown in continuous writing. The arrow at position 239 marks the $5^{\prime}$ end of the S59/4 cDNA. Polymorphic differences of the S59/4 cDNA sequence to that of the S59/2 cDNA are shown in italics. The S59/4 cDNA has an extension of 56 nucleotides at the $3^{\prime}$ end. The homeo domain is boxed. The PRD repeat is underlined with a solid line, and more scattered His/Pro - and histidine-rich sequences are marked with a dashed line. The arrowheads indicate the boundaries between exons. (B) A schematic diagram of the predicted 559 protein. As in $A$, the arrowheads indicate the exon boundaries. $(C)$ Comparison of the S59 homeo domain sequence with sequences of related homeo domains. Only amino acids that differ from the S59 sequence are shown. (D) Sequence comparison of the PRD repeats from S59, prd, and bicoid. His/Pro sequences and other amino acids shared by at least two of the genes are shaded. 
S59 expression in mesodermal precursor cells
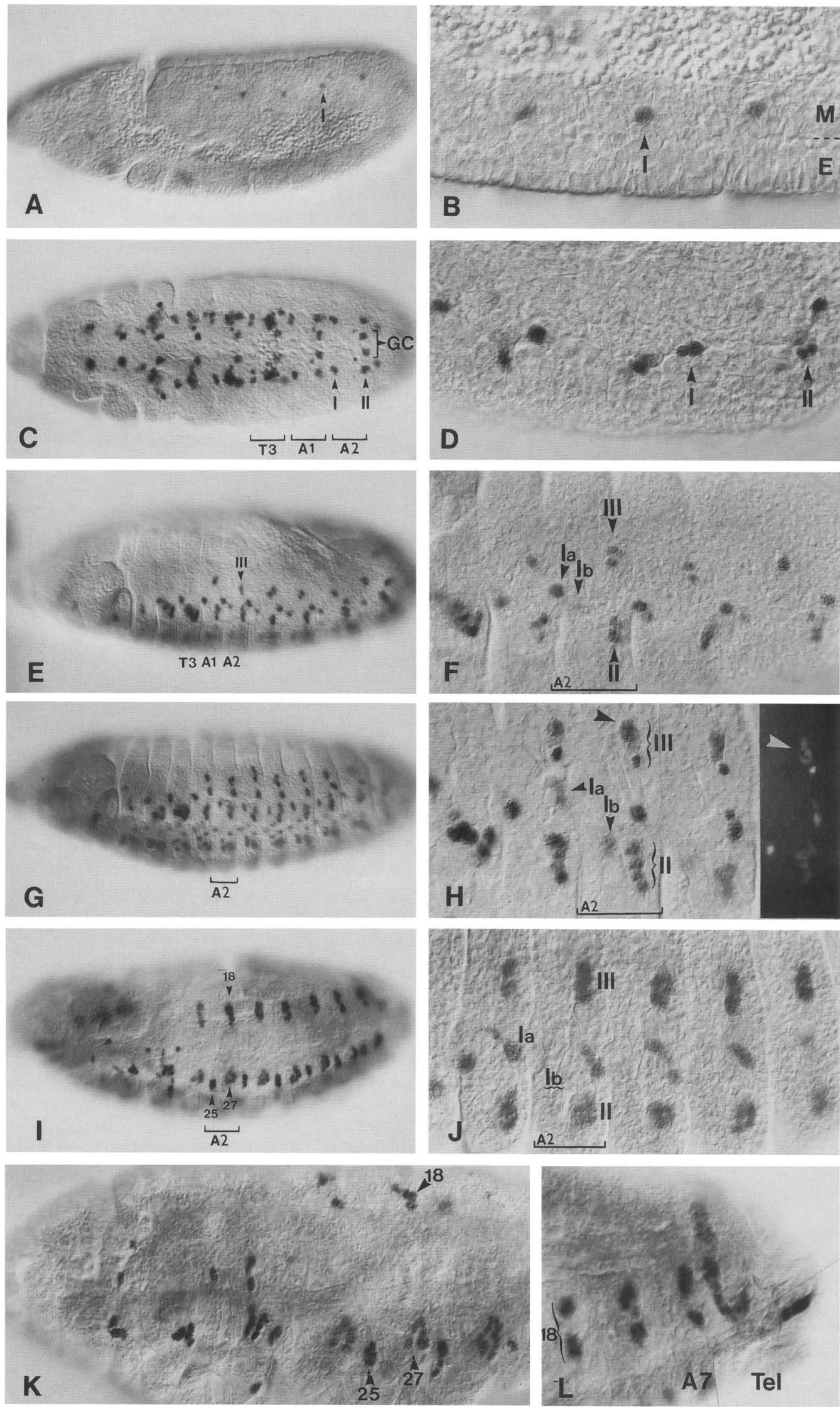

Figure 4. (See following page for legend.) 
we counted a three- to fivefold increase in the number of nuclei stained for S59 after syncytium formation. There is almost no myosin expression at this stage. In stages 14-16, these syncytia begin to differentiate into muscles 25 and 27 and strongly express myosin (Fig. $5 \mathrm{~F}-\mathrm{H}$ ). In later stages, the muscles stretch, resulting in an elongation and clustering of the nuclei. As an example, the fully differentiated pleural muscle groups, including muscle 18, are shown in Figure 5I.

Expression in the midgut and the CNS In stage 15, after the anterior and posterior primordia of the midgut have fused and surrounded the yolk sac, S59 protein is also expressed in cells of the midgut. The expression is confined to a narrow belt of endodermal cells, directly anterior to the first constriction that will appear somewhat later at this position (Fig. 7A). In late-stage embryos, all cells of the loop derived from this region of the midgut contain S59 protein (Fig. 7B). The level of S59 expression in midgut cells is lower than in the somatic mesoderm, as judged by the reduced staining intensity.

S59 expression in the CNS starts shortly after mesodermal expression. In early stage-11 embryos, a single neuronal precursor anterior and medial to mesodermal cell I is stained with S59 antibody in each segment (Fig. $5 \mathrm{~A}$. On the basis of the small size of this cell, we identify it as a ganglion mother cell rather than a neuroblast. During late stage 11 and stage 12, a cluster of several adjacent cells is found at this position, and a separate cluster of S59-positive ganglion mother cells gradually appears (Figd. 4C and 7C). After germ-band retraction, most of these cells assume a V-shaped arrangement in each ganglion in a pattern that is rather constant along the anterior/posterior axis (Fig. 7D). Upon contraction of the CNS, most of the S59-expressing neurons become located lateral to the axonal fiber tracts (Fig. 7E). Horizontal sections and cross sections show that S59-expressing neurons are present both in dorsal and ventral parts of the ventral nerve cord (Fig. 7E and F). Further- more, we observe S59 protein in distinct cells of the supraesophageal ganglion (Fig. 7B).

\section{Discussion}

We have presented a molecular analysis of a new Drosophila homeo box gene and determined its pattern of expression during embryogenesis. This gene, S59, is one of the few known Drosophila homeo box genes with an expression restricted to postgastrulation-stage embryos and to internal tissues. The other examples reported are H2.0, which is expressed in the visceral mesoderm; BSH4 of the gooseberry locus, which is expressed in specific neurons of the CNS; and cut, which is expressed mainly in external sensory organs (Barad et al. 1988; Blochlinger et al. 1988; Bopp et al. 1989). Among the homeo box genes described so far, S59 is the only one expressed in a small number of somatic muscles and their precursor cells. In contrast with S59, homeotic genes like $U b x$ are more generally expressed in the mesoderm, as well as in many other tissues including the epidermis (White and Wilcox 1985; Hooper 1986).

Although S59 was isolated using the homeo box of Scr, the homeo domains of both genes share only $49 \%$ amino acid identity (Kuroiwa et al. 1985). It is intriguing that the sequence of the S59 homeo domain has been highly conserved in evolution. Genes encoding almost identical homeo domains exist in such distantly related species as the honey bee and chicken. A homeo domain from $C$. elegans with a somewhat more diverged sequence belongs to the same class. It will be interesting to see whether these genes are expressed in patterns analogous to that of S59. Examples for similarities between the expression patterns of homeotic genes of $\mathrm{DrO}$ sophila and their vertebrate homologs have been reported (Duboule and Dollé 1989; Graham et al. 1989). In an evolutionary context, it may be significant that one of the Drosophila genes with a homeo domain most

Figure 4. Expression of $S 59$ protein in embryos. Whole-mount embryos $(A, C, E, G, I)$ and sectioned embryos $(B, D, F, H, I, K, L)$ are positioned so that anterior is to the left and dorsal is up. $(A)$ Early-stage 11 embryo. $S 59$ is expressed in a single, large mesodermal cell per hemisegment (I). Only the cells of the abdominal segments A4-A8 are in focus. $(B)$ High-magnification view of a sectioned embryo of the same stage as in $A$. The epidermal $(E)$ and mesodermal $(M)$ germ layers are indicated. (C) Late-stage 11 embryo (ventral view). S59 is now expressed in two mesodermal cell clusters per hemisegment (I and II) and also in two clusters of ganglion mother cells (GC). (D) High-magnification view of mesodermal clusters I and II in a sectioned late-stage 11 embryo. II cells are at the tips of the parasegmental bulges of the mesoderm. $(E)$ Stage 12 embryo. In abdominal segments, two additional mesodermal cells (cluster III) in dorsolateral positions express S59. (F) High-magnification view of the T3-A4 region. The daughter cells of I, Ia and Ib, start to migrate apart. $(G)$ Stage 13 embryo. Each abdominal segment contains four clusters of mesodermal cells expressing S59. The pattern in more anterior segments has diverged. S59-expressing cells in the ventral portion of the embryo belong to the CNS. $(H)$ High-magnification view of T3-A4 in stage 13. The dorsal cells of cluster III have just fused with more dorsally located myoblasts resulting in a spreading and transient reduction of the S59 signal (arrowhead). This event of the spreading of the S59 protein after fusion is seen more clearly using fluorescent staining, as shown for A4 (right). Here, again, the dorsal cell of cluster III has already fused with other myoblasts, and all four nuclei of the syncytium contain S59 at a reduced level (arrowhead). The ventral III cell and the Ib cell have not yet fused, and their nuclei have high levels of S59. (I) Stage 15 embryo. In abdominal segments, all S59 stained nuclei are contained in muscular syncytia. The numbers of these muscles correspond to the nomenclature of Crossley (1978). S59 expression in the syncitia derived from Ia cells has ceased. (/) High-magnification view of segments T3-A5 of a stage 14 embryo. At this stage, the fusion process of S59-expressing cells with surrounding myoblasts has just been completed. The nuclei of the Ib clusters (muscle 25) are not in the focal plane. $(K)$ S59-expressing muscles in segments T1-A3 of a stage-16 embryo. At this stage, the muscles are fully differentiated and each type of muscle has a characteristic local distribution of its nuclei. The S59-expressing muscle fibers in the thorax could not be correlated with any of the larval muscles described earlier (Campos-Ortega and Hartenstein 1975). (L) Posterior end of a stage 16 embryo. In the telson, four muscles express S59. They correspond to pll, srm, petl, and diol, according to Campos-Ortega and Hartenstein (1985). 

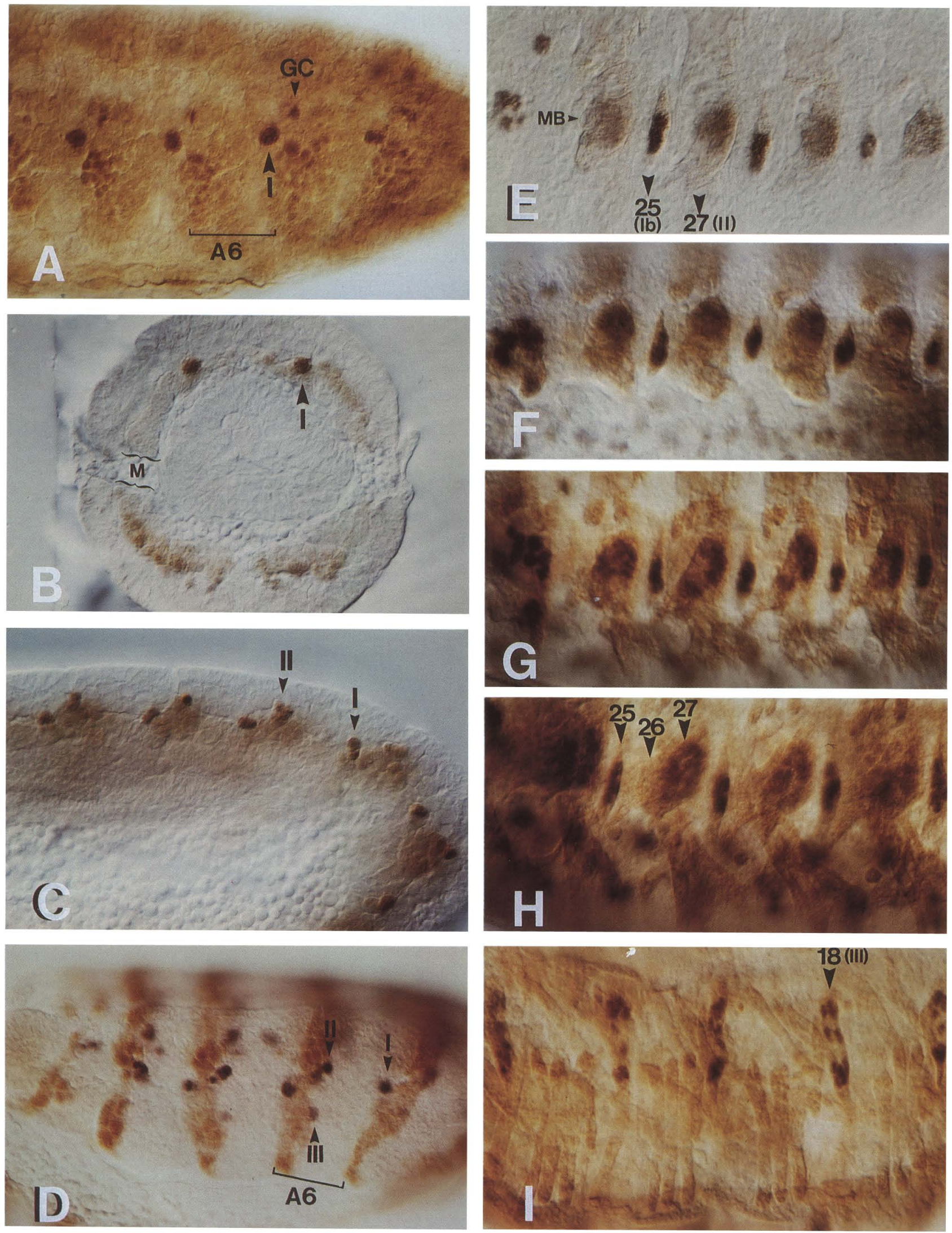

Figure 5. (See following page for legend.) 
closely related to that of $\mathrm{S} 59$, msh, also seems to be expressed in muscles (Robert et al. 1989). When isolating and analyzing genomic regions flanking S59, we found that $\mathrm{S} 59$ is a member of a new cluster containing at least four homeo box genes (M. Frasch, unpubl.; see also Kim and Nirenberg 1989). It remains to be seen whether any of the other homeo box genes of this cluster have functions related to that of $\$ 59$ and whether the cluster as a whole has been conserved in evolution.

The regulatory mechanisms activating S59 expression in a small number of defined mesodermal cells must be rather intricate. It is likely that spatial information from earlier pattern formation events is passed on in the mesoderm and becomes further refined. Since most of the segmentation genes are no longer expressed in the mesoderm at the time S59 appears, intermediary genes like twist, pox meso, and the mesodermally expressed homeotic genes may regulate S59 expression (White and Wilcox 1985; Thisse et al. 1988; Bopp et al. 1989). Double staining with $U b x$ and S59 antibodies indicates that there are mesodermal cells containing both proteins; and in embryos mutant for $U b x$, we observe alterations of the S59 expression pattern (M. Frasch, unpubl.). Although it is not yet clear that this is a direct interaction, we assume that inputs from the homeotic genes result in the modulation of S59 expression along the anterior/posterior axis of the embryo. It is also possible that signals transmitted from epidermal regions contribute to the activation of S59 in defined mesodermal cells.

Interestingly, S59 expression in the midgut corresponds to a region where the homeo box gene labial is also expressed (Diederich et al. 1989). In the same region, cells of the visceral mesoderm contacting the endoderm express $U b x$ (Akam and Martinez-Arias 1985; Tremml and Bienz 1989); decapentaplegic (dpp), encoding a gene product with homology to vertebrate TGF- $\beta$ (Padgett et al. 1987; St. Johnston and Gelbart 1987); and wingless (wg), which is also thought to be involved in cell-cell communication (van den Heuvel et al. 1989). Ubx, dpp, and wg are required for normal expression of labial in the endoderm (Immerglück et al. 1990). It is possible that S59 is a second endodermal target of this cascade of inductive interactions, being activated either in parallel to labial or downstream of it.
The expression of S59 in specific mesodermal cells and muscles provides new insights into how particular muscles develop. It appears that founder cells exist for each of the scored muscles at an early stage of mesodermal development. The first of these cells can be distinguished by their S59 expression at $\sim 2 \mathrm{hr}$ after mesodermal invagination, shortly before they undergo their last division. The founder cells for the other muscles can be detected slightly later. The pattern of both their spatial and temporal appearance is exactly reproduced in each embryo. We do not observe extensive migration of these founder cells. In general, they remain at their original sites with respect to the compartmental borders of the overlying epidermis throughout development. However, we cannot exclude more extensive movements of other mesodermal cells. As an exception, the daughter cells of one S59-expressing cell (I) in each abdominal hemisegment do move apart a short distance and consequently end up in two different segments. This suggests that, at least within each parasegment, there are no apparent compartmental restrictions. Similar results have also been obtained by lineage analyses of the mesoderm (Lawrence and Johnston 1982; Beer et al. 1987). In addition, the behavior of these cells shows that founder cells of two different types of muscles (in this case, 25 and 5) can be clonally related.

Large mesodermal cells serving as "muscle pioneers" have been observed in the early mesodermal development of grasshoppers (Ho et al. 1983). Their properties are reminiscent of those of the 559-expressing founder cells in that they are larger than other mesodermal cells, they appear early, and they seem to organize other myoblasts into muscle fibers. The occurrence of muscle pioneers in Drosophila has been suggested by Leiss et al. (1988) and Johansen et al. (1989). However, further analysis, including dye injection followed by antibody staining, is required to confirm a correlation between S59-expressing cells and muscle pioneers.

The genetic mechanisms involved in the formation of the embryonic muscle pattern are largely unknown. An important and still open question is to what degree muscle development is regulated autonomously, that is, through programs intrinsic to the mesoderm. For muscle development during metamorphosis, evidence for a nonautonomous specification has been obtained from mo-

Figure 5. Expression of S59 in mesodermal cells and muscle fibers. $(A-C)$ Embryos were double stained with S59 antibodies (dark brown) and twist antibodies (light brown). (A) Early-stage 11 embryo. A dorsal view of the elongated germ band is shown (segments A4-A8). The more anterior parts of the germ band are to the right. S59 appears in the nucleus of one large mesodermal cell (I) per hemisegment. More medially, a single ganglion mother cell (GC) stains for S59. (B) Cross section through a similar embryo as in $A$. In the mesodermal layer (M) of the dorsal part of the embryo, two S59-stained cells I are seen. twist expression in the mesoderm is segmentally modulated at this stage and is therefore uneven. (C) Section through a late-stage 11 embryo (orientation as in $A$ ). In each segment, two daughter cells of I and at the parasegmental bulges of the mesoderm a cluster of II cells are seen. At these bulges, twist expression persists more strongly. (D) Stage 12 embryo double stained with S59 antibodies (purple) and engrailed antibodies (ocher). Orientation as in A. engrailed is expressed in the posterior compartments of the epidermis. S59-expressing mesoderm cells I are at the anterior segment border; cells II and cells III are at the anterior/posterior compartment border. (E-I) Embryos double stained with S59 antibodies (dark brown) and myosin antibodies (ocher). (E-H) Morphogenesis of the ventral muscle group in the segments T3-A4. (E) Stage 13. Syncitia have just formed. Unfused myoblasts (MB) are also still present. $(F)$ Stage 14. Myosin is accumulating in the syncytia. $(G$ and $H)$ Stages 15 and 16. The muscle fibers differentiate to assume their final shape. Muscles 27 contain $8-12$ S59-stained nuclei, muscles 25 have 4-6 nuclei. (I) Stage 16, pleural muscles of A2-A6. The muscles are fully differentiated. Muscles 18 contain $8-12$ S59-stained nuclei arranged in clusters at either end of the fibers (also seen in Fig. 4L). 

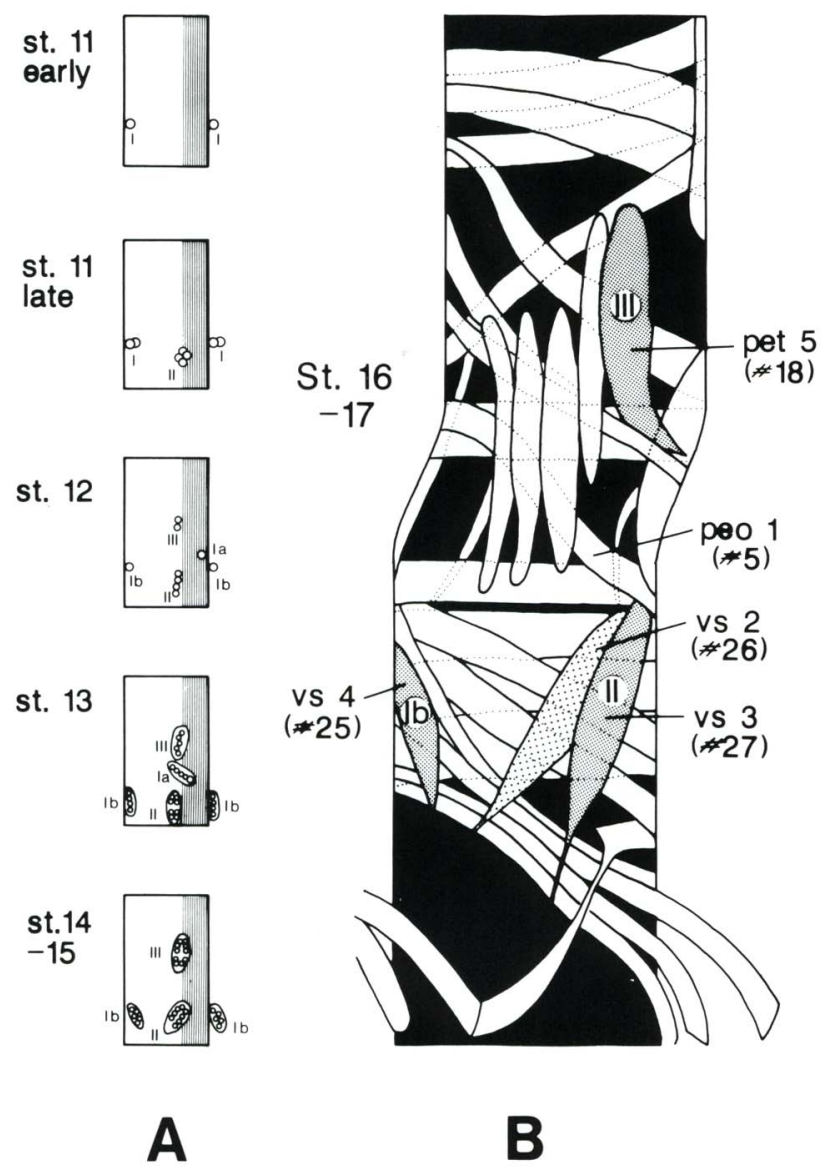

Figure 6. Schematic diagram of the development of S59-expressing muscles in an abdominal segment. Each box in $A$ represents an abdominal segment A2-A7 in different stages of development. The shaded area corresponds to the posterior compartment of the epidermis. Note that the posterior parts of the segments are pulled into the segmental furrows after stage 11 , and the muscles form attachment sites at the apodemes. In $B$, the muscle pattern of an abdominal hemisegment in a latestage embryo is shown. The scheme is a compilation from segments A2-A7 of several embryos stained for muscular myosin. The S59-expressing muscles are shaded and named according to the nomenclature of Crossley (1978) and Campos-Ortega and Hartenstein (1975). S59 protein has disappeared from muscle $5 /$ peol at this stage. Staining of $26 / v s 2$ is extremely weak and might be due to a transient coupling with $27 / \mathrm{vs} 3$ (Johansen et al. 1989). The muscle pattern in Al shows several differences including the absence of muscle 25 .

saic analysis (Lawrence and Johnston 1986). Although motor neurons have been implicated in the induction of adult muscles, the epidermis rather than motor neurons may provide such signals in the embryo (Johansen et al. 1989). We do not know at what stage of embryonic development mesodermal cells become committed to particular muscular fates. In transplantation experiments, Beer et al. (1987) found that shortly after their invagination, mesodermal cells are not yet committed to form particular muscles or even particular mesodermal tissues. The expression of S59 in several defined mesodermal cells $\sim 2 \mathrm{hr}$ later suggests that at least some me- sodermal cells are singled out and assume a specific fate in the late phase of their proliferation or shortly thereafter. Thus, if inductive mechanisms are important for embryonic mesoderm development, such events are likely to occur at this early stage of mesodermal development. We suggest that later steps of muscle development are mainly determined by regulatory programs within the mesoderm. Because the homeo domain protein S59 is likely to act as a transcription factor, the S59 gene could well be one component in setting up distinct differentiation pathways for particular cells. Therefore, we favor a role of S59 for the specification of myoblast and muscle identities. We assume that other genes with an analogous function are expressed in the precursor cells of muscles that do not express S59. In the CNS, S59 may perform a similar function for neuronal specification. To determine the function of S59, we are currently performing a genetic screen to isolate mutants for this homeo box gene.

\section{Materials and methods}

\section{Library screens for genomic clones and cDNA clones}

The procedure used to isolate genomic clones under conditions of low stringency for hybridization with the Scr homeo box probe has been described previously (Levine et al. 1985).

Phage clones overlapping with the original S59 clone were isolated from a library provided by $\mathrm{M}$. Goldberg consisting of partially digested Sau3A fragments of genomic Drosophila DNA cloned into BamHI-digested $\lambda$ EMBL4 arms. The Drosophila embryonic cDNA libraries were a generous gift from $\mathrm{L}$. Kauvar and N. Brown. The Kauvar library consisted of 3- to 12-hr embryonic cDNAs cloned into $\lambda$ gt 10 phage vectors. The Brown libraries contained 8- to 12 -hr cDNAs and 12- to 24-hr cDNAs. These cDNAs were cloned into the plasmid vector pNB40 in a single orientation, such that the leader sequence of Xenopus $\beta$-globin became ligated to the $5^{\prime}$ end of each cDNA (Brown and Kafatos 1988). The cDNAs described in Results were obtained from the Brown libraries.

\section{Sequencing}

cDNAs and fragments of genomic DNA were subcloned into pBluescript KS + and SK + (Stratagene). After restriction mapping, deletions were created with appropriate restriction enzymes. Single-stranded templates were obtained by superinfection of XL1-blue cells harboring these constructs with R-408 helper phages (Bullock et al. 1987). Sequencing was performed by the dideoxynucleotide sequencing method of Sanger et al. (1977), using a modified form of T7 polymerase (Sequenase, U.S. Biochemicals|. Both strands of the S59/2 cDNA and the $3^{\prime}$ end of the S59/4 cDNA were sequenced.

\section{Northern analysis}

Total RNA was prepared by grinding embryos, larvae, and adult flies frozen in liquid nitrogen in a mortar followed by extraction with a buffer containing $3 \mathrm{M} \mathrm{LiCl}, 6 \mathrm{M}$ urea, $0.1 \%$ SDS, $10 \mathrm{~mm}$ $\mathrm{Na}$ acetate $\{\mathrm{pH} 5.6\}$, and $200 \mathrm{mg} / \mathrm{ml}$ heparin. The RNA was precipitated in this buffer overnight, washed twice with $3 \mathrm{M} \mathrm{LiCl}$ and $6 \mathrm{M}$ urea, and dissolved in $50 \mathrm{mM} \mathrm{Na}$ acetate $(\mathrm{pH} 5.6), 1 \%$ SDS. After ethanol precipitation poly $(\mathrm{A})^{+}$RNA was isolated using oligo(dT)-cellulose (BRL). After heat denaturation in the 

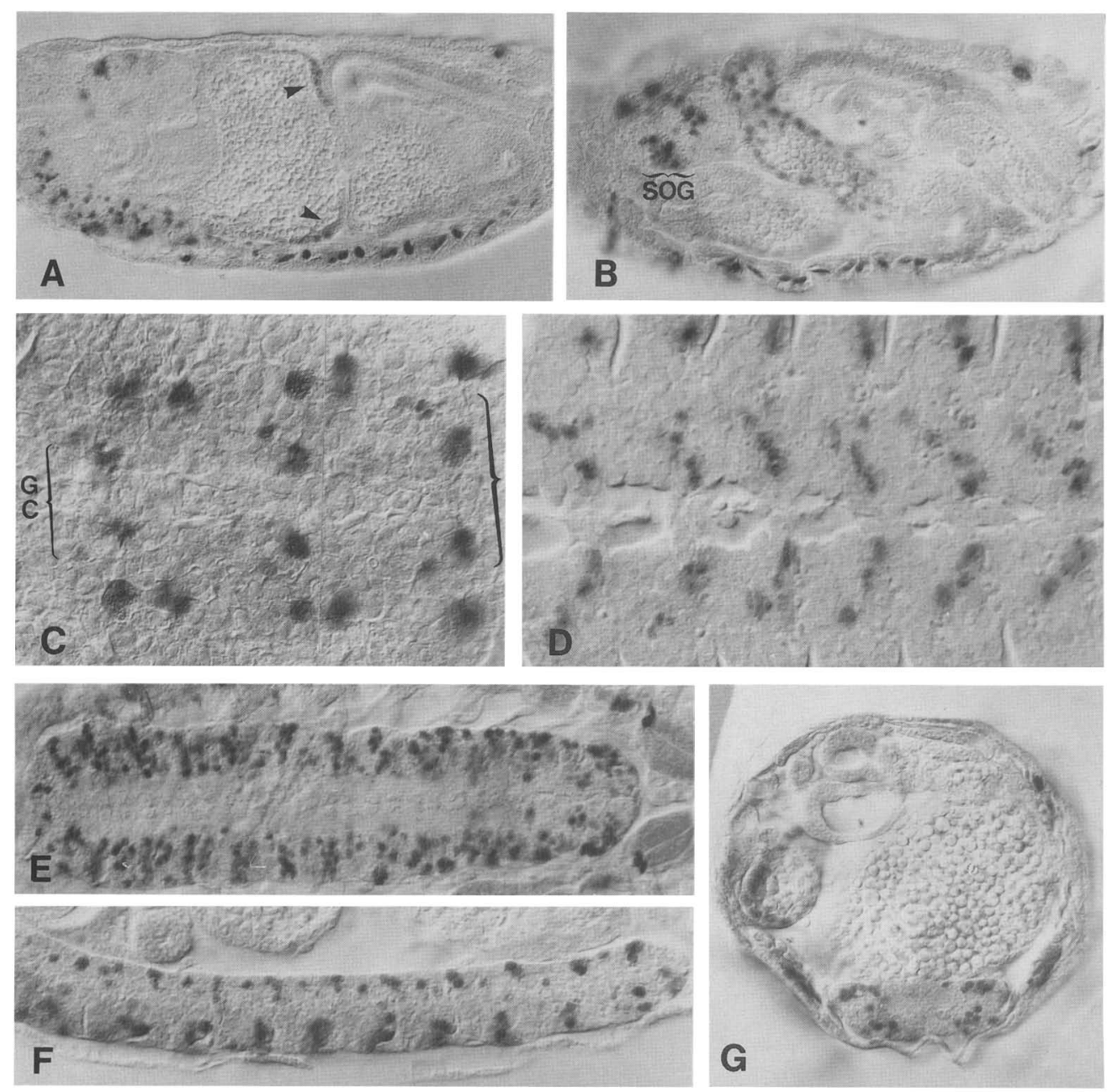

Figure 7. S59 expression in the midgut and in the CNS. Embryo sections are positioned so that anterior is to the left. (A) S59 is expressed just anterior to the constriction appearing first in the midgut (arrowheads $\mid \cdot(B \mid$ In late-stage embryos, endodermal cells of a whole loop of the midgut express S59. More anteriorly, cells of the supraesophageal ganglion (SOG) stain for S59. (C) High-magnification view of the mid-ventral germ band of a stage 11 embryo. On either side of the ventral midline, a cluster of four to six and one or two separate, more anteriorly located ganglion mother cells (GC) express S59 at this stage. Cells stained more laterally are the mesodermal cells I and II. $(D)$ Section through the CNS of a stage 13 embryo showing 559 expression in the ganglia of A1-A6. (E) Tangential, $\{F\rangle$ sagittal, and $(G)$ transverse sections through the ventral cord of stages $15-16$ embryos. In $F$ and $G$, S59-expressing neurons in both the dorsal and ventral portions of the ganglia are seen. The section in $E$ is through the ventral portion of the nerve cord. Because of its curvature, neurons located at the ventral surface are in focus in the posterior part and somewhat more interior neurons are seen in the other parts.

presence of $0.66 \mathrm{M} \mathrm{HCHO}$ and $50 \%$ formamide, these RNAs were separated on a $1.5 \%$ agarose gel under denaturing conditions $[3.7 \%$ formaldehyde, $20 \mathrm{mM} N$ - $\{2$-hydroxy ethyl $\}$-piperazine-N'3-propane sulfonate $(\mathrm{pH} 8.2), 100 \mathrm{~mm}$ Na acetate, $1 \mathrm{mM}$ EDTA]. The RNA was transferred onto a nylon filter and probed with the S59/2 cDNA radiolabeled with the random priming procedure of Feinberg and Vogelstein (1984).

\section{Preparation of S59 fusion proteins and 559 antibodies}

For the production of 559 proteins in Escherichia coli, a pUR expression vector (Rüther and Müller-Hill 1983) and the pT7-7 vector (Tabor and Richardson 1985; S. Tabor, unpubl.) were employed. An 880-bp partial BamHI-XbaI fragment corresponding to the $3^{\prime}$ third of the S59/2 cDNA was cloned into pUR 278. The expression and purification of the LacZ/S59 fu- sion protein was performed as described in Frasch et al. (1987). This fusion protein was used for the first immunization and two subsequent boosts of a rabbit ("Sifty"). The antibody used for the experiments was obtained after two additional boosts with an $\mathrm{S} 59$ protein obtained with the $\mathrm{T} 7$ expression construct. For this construct, a $1.7-\mathrm{kb}$ Pst $-C l a I$ fragment excised from $\mathrm{S} 59 / 2$ in pBluescript was cloned into pT7-7. This construct produced a protein consisting of 13 amino acids from the vector and 471 amino acids from 559 . To produce this protein, BL21(DE3)LysS cells (Studier and Moffat, 1986; F.W. Studier, unpubl.) containing the plasmid were grown in $\mathrm{L}$ broth, $20 \mathrm{~mm}$ glucose, $200 \mu \mathrm{g} / \mathrm{ml}$ ampicillin, to an optical density of 0.5 , transferred into fresh medium, and induced with $1 \mathrm{mM}$ IPTG for $30 \mathrm{~min}$. After addition of rifampicin $(200 \mu \mathrm{g} / \mathrm{ml})$ and incubation for another $1.5 \mathrm{hr}$ at $37^{\circ} \mathrm{C}$ the bacterial pellet was collected, resuspended in PBS, and treated with $1 \mathrm{mg} / \mathrm{ml}$ of lyso- 
zyme for $1 \mathrm{hr}$ at $0^{\circ} \mathrm{C} . \mathrm{NaCl}(500 \mathrm{mM})$ and $0.5 \%$ Tween 80 were added and after $15 \mathrm{~min}$ the bacteria were sonicated thoroughly. The insoluble 559 protein was pelleted, dissolved in extraction buffer [ $8 \mathrm{M}$ urea, $0.5 \mathrm{M} \mathrm{NaCl}, 0.5 \mathrm{M}$ Tris- $\mathrm{HCl}(\mathrm{pH} 8), 1 \mathrm{~mm}$ EDTA, $30 \mathrm{mM} \beta$-mercaptoethanol], and dialyzed against PBS. For the rabbit immunization, S59 protein was further purified from the precipitate formed after dialysis by preparative SDSPAGE. For affinity purification of the serum, the precipitate was dissolved in $0.1 \mathrm{M} \mathrm{NaHCO}_{3}$ buffer $(\mathrm{pH} 8.3), 6 \mathrm{M}$ guanidinium- $\mathrm{HCl}$, and $0.5 \mathrm{M} \mathrm{NaCl}$ and conjugated to $\mathrm{CNBr}$-activated Sepharose (Pharmacia). Antibodies directed against other bacterial proteins and antibodies with unspecific affinities to Drosophila embryos were removed with affinity columns prepared similarly using bacterial extracts or total proteins from 0 - to 4-hr embryos.

\section{Antibody stainings}

For antibody stainings of whole-mount embryo preparations, the embryos were fixed and incubated with the first antibody as described in Frasch et al. (1987). The secondary antibody was a biotinylated horse anti-rabbit IgG, and an avidin/biotin/horseradish peroxidase (HRP) complex was used for the detection (VECTASTAIN from Vector Laboratories). The HRP substrate was diaminobenzidine (DAB) with $\mathrm{CoCl}_{2}$ and $\mathrm{NiSO}_{4}(0.03 \%$ each; Adams 1981) in PBS. Double stainings were performed as in Lawrence and Johnston (1989), omitting the $\mathrm{Co}^{2+}$ and $\mathrm{Ni}^{2+}$ in the first reaction. After staining, the embryos were dehydrated and mounted in Permount. For sections $(25 \mu \mathrm{m})$, the embryos were embedded in araldite (Roth et al. 1989). Photographs were taken with Nomarski optics on a Zeiss Axiophot microscope. Kodak Ektachrome EPT-160 with correction filters KR1.5-KR6 was used for color photographs, and Kodak technical pan was used for black-and-white photographs.

\section{Acknowledgments}

We thank Michael Levine for discussions and encouragement in the initial stages of the project, Hanna Radomska for isolating a cDNA, Meike Müller for technical assistance, Dan Kiehart for providing the myosin antibody, Siegfried Roth for the twist antibody, Nick Brown and Larry Kauvar for cDNA libraries, Yosef Gruenbaum for communicating sequences, and Helen Doyle, Daniel St. Johnston, Rolf Reuter, Dave Stein, and Paul Whitington for helpful comments on the manuscript. Part of this work was supported by a grant of the Deutsche Forschungsgemeinschaft.

The publication costs of this article were defrayed in part by payment of page charges. This article must therefore be hereby marked "advertisement" in accordance with 18 USC section 1734 solely to indicate this fact.

\section{Note added in proof}

Sequence data described in this paper have been submitted to EMBL/GenBank Data Libraries under accession number X55393.

\section{References}

Adams, I.C. 1981. Heavy metal intensification of DAB-based HRP reaction product. I. Histochem. Cytochem. 29: 775.

Akam, M.E. and A. Martinez-Arias. 1985. The distribution of Ultrabithorax transcripts in Drosophila embryos. EMBO $\mathrm{J}$. 4: 3757-3764.

Barad, M., T. Jack, R. Chadwick, and W. McGinnis. 1988. A novel, tissue specific, Drosophila homeobox gene. EMBO $\mathrm{J}$. 7: 2151-2161.

Baumgartner, S., D. Bopp, M. Burri, and M. Noll. 1987. Structure of two genes at the gooseberry locus related to the paired gene and their spatial expression during Drosophila embryogenesis. Genes Dev. 1: 1247-1267.

Beer, J., G.M. Technau, and J.A. Campos-Ortega. 1987. Lineage analysis of transplanted individual cells in embryos of Drosophila melanogaster. Wilhelm Roux's Arch. Dev. Biol. 196: $221-230$.

Berleth, T., M. Burri, G. Thoma, D. Bopp, S. Richstein, G. Frigerio, M. Noll, and C. Nüsslein-Volhard. 1988. The role of localization of bicoid mRNA in organizing the anterior pattern of the Drosophila embryo. EMBO J. 7: 1749-1756.

Blochlinger, K., R. Bodmer, J. Jack, L.Y. Jan, and Y.N. Jan. 1988. Primary structure and expression of a product from cut, a locus involved in specifying sensory organ identity in Drosophila. Nature 333: 629-635.

Bopp, D., E. Jamet, S. Baumgartner, M. Burri, and M. Noll. 1989. Isolation of two tissue-specific Drosophila paired box genes, pox meso and pox neuro. EMBO I. 8: 3447-3457.

Brown, N.H. and F.C. Kafatos. 1988. Functional cDNA libraries from Drosophila embryos. I. Mol. Biol. 203: 425-437.

Bullock, W.O., J.M. Fernandez, and J.M. Short. 1987. XL1-Blue: A high-efficiency plasmid transforming recA Escherichia coli strain with beta-galactosidase selection. BioTechniques 5: 376-377.

Campos-Ortega, J.A. and V. Hartenstein. 1985. The embryonic development of Drosophila melanogaster. Springer, Berlin.

Cavener, D.R. 1987. Comparison of the consensus sequence flanking translational start sites in Drosophila and vertebrates. Nucleic Acids Res. 15: 1353-1361.

Crossley, A.C.S. 1965. Transformations in the abdominal muscles of the blow-fly, Calliphora erythrocephala (Meig), during metamorphosis. J. Embryol. Exp. Morphol. 14: 89110.

- 1978. The morphology and development of the Drosophila muscular system. In The genetics and biology of Drosophila (ed. M. Ashburner and T.R.F. Wright), vol. 2b, pp. 499-560. Academic Press, London.

Dalton, D., R. Chadwick, and W. McGinnis. 1989. Expression and embryonic function of empty spiracles: A Drosophila homeo box gene with two patterning functions on the anterior-posterior axis of the embryo. Genes Dev. 3: 19401956.

Desplan, C., J. Theis, and P.H. O'Farrell. 1985. The Drosophila developmental gene, engrailed, encodes a sequence-specific DNA binding activity. Nature 318: 630-635.

Diederich, R., V. Merrill, M. Pultz, and T. Kaufman. 1989. Isolation, structure, and expression of labial, a homeotic gene of the Antennapedia complex involved in Drosophila head development. Genes Dev. 3: 399-414.

Doe, Q.C. and M.P. Scott. 1988. Segmentation and homeotic gene function in the developing nervous system of Drosophila. Trends Neurosci. 11: 101-106.

Doe, Q.C., Y. Hiromi, W.J. Gehring, and C. Goodman. 1988a. Expression and function of the segmentation gene fushi tarazu during Drosophila neurogenesis. Science 239: 170175.

Doe, Q.C., D. Smouse, and C.S. Goodman. 1988b. Control of neuronal fate by the Drosophila segmentation gene evenskipped. Nature 333: 376-378.

Duboule, D. and P Dollé. The structural and functional organization of the murine HOX gene family resembles that of Drosophila homeotic genes. EMBO I. 8: 1497-1505.

Feinberg, A.P. and B. Vogelstein. 1984. A technique for radiola- 
beling DNA restriction endonuclease fragments to high specific activity. Addendum. Anal. Biochem. 137: 266-267.

Frasch, M., T. Hoey, C. Rushlow, H. Doyle, and M. Levine. 1987. Characterization and localization of the even-skipped protein of Drosophila. EMBO J. 6: 749-759.

Frigerio, G., M. Burri, D. Bopp, S. Baumgartner, and M. Noll. 1986. Structure of the segmentation gene paired and the Drosophila PRD gene set as part of a gene network. Cell 47: 735-746.

Graham, A., N. Papalopulu, J. Lorimer, and R. Krumlauf. 1989. The murine and Drosophila homeobox complexes have common features of organization and expression. Cell 57: 367-378.

Ho, R.K., E.F. Ball, and C.S. Goodman. 1983. Muscle pioneers: Large mesodermal cells that erect a scaffold for developing muscles and motoneurons in grasshopper embryos. Nature 301: 66-69.

Hoey, T. and M. Levine. 1988. Divergent homeo box proteins recognize similar DNA sequences in Drosophila. Nature 332: $858-861$.

Hooper, J.E. 1986. Homeotic gene function in the muscles of Drosophila larvae. EMBO I. 5: 2321-2329.

Hope, T.A. and K. Struhl. 1986. Functional dissection of a eukaryotic transcriptional activator protein, GCN4 in yeast. Cell 46: 885-894.

Hultmark, D., R. Klemenz, and W.J. Gehring. 1986. Translational and transcriptional control elements in the untranslated leader of the heat shock gene hsp22. Cell 44: 429-438.

Immerglück, K., P.A. Lawrence, and M. Bienz. 1990. Induction across germ layers in Drosophila mediated by a genetic cascade. Cell 62: 261-268.

Ingham, P.W. 1988. The molecular genetics of embryonic pattern formation in Drosophila. Nature 335: 25-34.

Johansen, J., M.E. Halpern, and H. Keshishian. 1989. Axonal guidance and the development of muscle fiber-specific innervation in Drosophila embryos. I. Neurosci. 9: 43184332.

Jürgens, G., E. Wieschaus, C. Nüsslein-Volhard, and H. Kluding. 1984. Mutations affecting the pattern of the larval cuticle in Drosophila melanogaster. Wilhelm Roux's Arch. Dev. Biol. 193: 359-377.

Kim, Y. and M. Nirenberg. 1989. Drosophila NK-homeobox genes. Proc. Natl. Acad. Sci. 86: 7716-7720.

Kuroiwa, A., U. Kloter, P. Baumgartner, and W.J. Gehring. 1985. Cloning of the homeotic Sex comb reduced gene in Drosophila and in situ localization of its transcripts. EMBO $J$. 4: 3757-3764

Kuziora, M.A. and W. McGinnis. 1989. A homeodomain substitution changes the regulatory specificity of the Deformed protein in Drosophila embryos. Cell 59: 563-571.

Lawrence, P.A. and P. Johnston. 1982. Cell lineage of the Drosophila abdomen: The epidermis, oenocytes and ventral muscles. J. Embryol. Exp. Morphol. 72: 197-208.

1986. The muscle pattern of Drosophila may be determined by neurons and not by contributing myoblasts. Cell 45: 505-513.

-1989. Pattern formation in the Drosophila embryo: Allocation of cells to parasegments by even-skipped and fushi tarazu. Development 105: 761-767.

Lehmann, R., F. Jimenez, U. Dietrich, and J.A. Campos-Ortega. 1983. On the phenotype and development of mutants of early neurogenesis of Drosophila melanogaster. Wilhelm Roux's Arch. Dev. Biol. 192: 62-74.

Leiss, D., U. Hinz, A. Gasch, R. Mertz, and R. Renkawitz-Pohl. 1988. $\beta 3$ tubulin expression characterizes the differentiating mesodermal germ layer during Drosophila embryogenesis.
Development 104: 525-531.

Levine, M., K. Harding, C. Wedeen, H. Doyle, T. Hoey, and H. Radomska. 1985. Expression of the homeo box gene family in Drosophila. Cold Spring Harbor Symp. Quant. Biol. 50: 209-222.

Lewis, E.B. 1978. A gene complex controlling segmentation in Drosophila. Nature 276: 565-570.

Ma, J. and M. Ptashne. 1987. Deletion analysis of GAL4 defines two transcriptional activating segments. Cell 48: 847-853.

McGinnis, W., M. Levine, E. Hafen, A. Kuroiwa, and W.J. Gehring. 1984. A conserved DNA sequence found in homeotic genes of the Drosophila Antennapedia and Bithorax complexes. Nature 308: 428-433.

Nüsslein-Volhard, C. and E. Wieschaus. 1980. Mutations affecting segment number and polarity in Drosophila. Nature 287: $1675-1681$.

Nüsslein-Volhard, C., E. Wieschaus, and H. Kluding. 1984. Mutations affecting the pattern of the larval cuticle in Drosophila melanogaster. I. Zygotic loci on the second chromosome. Wilhelm Roux's Arch. Dev. Biol. 193: 267-282.

Padgett, R.W., R.D. St. Johnston, and W.M. Gelbart. 1987. A transcript from a Drosophila pattern gene predicts a protein homologous to the transforming growth factor-(beta) family. Nature 325: 81-84.

Poole, S.J., L.M. Kauvar, B. Drees, and T. Kornberg. 1985. The engrailed locus of Drosophila: Structural analysis of an embryonic transcript. Cell 40: 37-47.

Qian, Y.Q., M. Billeter, G. Otting, M. Müller, W.J. Gehring, and K. Wüthrich. 1989. The structure of the Antennapedia homeodomain determined by NMR spectroscopy in solution: Comparison with prokaryotic repressors. Cell 59: 573-580.

Rangini, Z., A. Frumkin, G. Shani, M. Guttmann, H. Eyal-Giladi, Y. Gruenbaum, and A. Fainsod. 1989. The chicken homeo box genes CHox1 and CHox3: Cloning, sequencing and expression during embryogenesis. Gene 76: 61-74.

Robert, B., D. Sassoon, B. Jacq, W. Gehring, and M. Buckingham. 1989. Hox-7, a mouse homeobox gene with a novel pattern of expression during embryogenesis. EMBO $\mathrm{J}$. 8: $91-100$.

Roth, S., D. Stein, and C. Nüsslein-Volhard. 1989. A gradient of nuclear localization of the dorsal protein determines dorsoventral pattern in the Drosophila embryo. Cell 59: 11891202.

Rushlow, C., H. Doyle, T. Hoey, and M. Levine. 1987. Molecular characterization of the zerknüllt region of the Antennapedia gene complex in Drosophila. Genes Dev. 1: 12681279.

Rüther, U. and B. Müller-Hill. 1983. Easy identification of cDNA clones. EMBO J. 2: 1791-1794.

Sanger, F., S. Nicklen, and A.R. Coulson. 1977. DNA sequencing with chain terminating inhibitors. Proc. Natl. Acad. Sci. 74: 5463-5476.

Scalenghe, F. and F. Ritossa. 1977. The puff inducible in region 93D is responsible for the major "heat shock" polypeptide in Drosophila melanogaster. Chromosoma 63: 317-326.

Scott, M.P., J.W. Tamkun, and G.W. Hartzell III. 1989. The structure and function of the homeo domain. Biochem. Biophys. Acta 989: 25-48.

St. Johnston, R.D. and W.M. Gelbart. 1987. Decapentaplegic transcripts are localized along the dorsal-ventral axis of the Drosophila embryo. EMBO I. 6: 2785-2791.

Studier, F.W. and B.A. Moffat. 1986. Use of bacteriophage T7 RNA polymerase to direct selective high level expression of cloned genes. J. Mol. Biol. 189: 113-130.

Tabor, S. and C.C. Richardson. 1985. A bacteriophage T7 RNA polymerase/promoter system for controlled exclusive ex- 
pression of specific genes. Proc. Natl. Acad. Sci. 82: 10741078.

Thisse, B., C. Stoetzel, C. Gorostiza-Thisse, and F. PerrinSchmitt. 1988. Sequence of the twist gene and nuclear localization of its protein in endomesodermal cells of early Drosophila embryos. EMBO J. 7: 2175-2183.

Tremml, G. and M. Bienz. 1989. Homeotic gene expression in the visceral mesoderm of Drosophila embryos. EMBO $\mathrm{J}$. 8: $2677-2685$.

van den Heuvel, M., R. Nusse, P. Johnston, and P. Lawrence. 1989. Distribution of the wingless gene product in Drosophila embryos: A protein involved in cell-cell communication. Cell 59: 739-749.

Walldorf, U., R. Fleig, and W.J. Gehring. 1989. Comparison of homeobox-containing genes of the honey bee and Drosophila. Proc. Natl. Acad. Sci. 86: 9971-9975.

White, R.A.H. and M. Wilcox. 1985. Distribution of Ultrabithorax proteins in Drosophila. EMBO I. 4: 2035-2043.

Wieschaus, E., C. Nüsslein-Volhard, and H. Kluding. 1984. Mutations affecting the pattern of the larval cuticle in Drosophila melanogaster. III. Zygotic loci on the X-chromosome and fourth chromosome. Wilhelm Roux's Arch. Dev. Biol. 193: 296-307. 


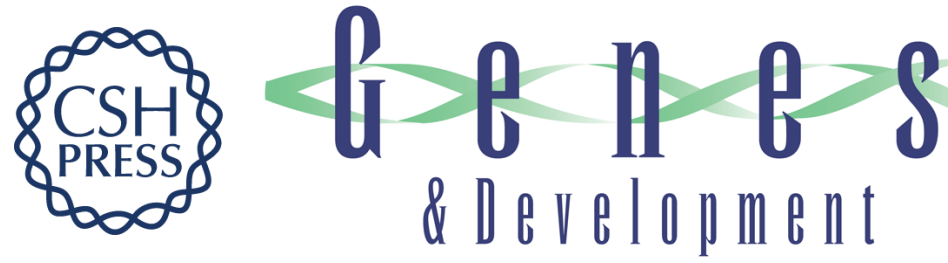

\section{A new Drosophila homeo box gene is expressed in mesodermal precursor cells of distinct muscles during embryogenesis.}

C Dohrmann, N Azpiazu and M Frasch

Genes Dev. 1990, 4:

Access the most recent version at doi:10.1101/gad.4.12a.2098

References This article cites 65 articles, 13 of which can be accessed free at:

http://genesdev.cshlp.org/content/4/12a/2098.full.html\#ref-list-1

License

Email Alerting

Service

Receive free email alerts when new articles cite this article - sign up in the box at the top right corner of the article or click here.

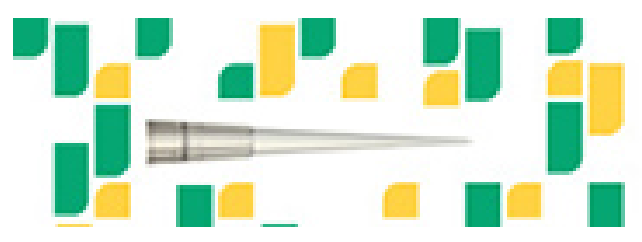

Focused on your science. 